\title{
Fabrication of Three-Dimensional Copper@Graphene Phase Change Composite with High Structural Stability and Low Leakage Rate
}

\author{
Xiaoming Li 1,†, Yidan Gao 1,†, Qingqiang Kong 1, Lijing Xie 1, Zhuo liu ${ }^{1}$, Xiaoqian Guo 1, Yanzhen Liu ${ }^{1}$, \\ Xianxian Wei ${ }^{3}$, Xiao Yang ${ }^{1}$, Xinghua Zhang ${ }^{1}$, Chengmeng Chen ${ }^{1,2, *}$ \\ ${ }^{1}$ Key Laboratory of Carbon Materials, Institute of Coal Chemistry, Chinese Academy of Sciences, Taiyuan 030001, China. \\ ${ }^{2}$ College of Materials Sciences and Opto-Electronic Technology, University of Chinese Academy of Sciences, Beijing 100049, China. \\ ${ }^{3}$ College of Environment and Safety, Taiyuan University of Science and Technology, Taiyuan 030024, China.
}

\begin{abstract}
Owing to the continuous increase in energy consumption and the growing depletion of traditional fossil fuels, the development of renewable energy is becoming increasingly urgent. Renewable energy has come to the fore, represented by geothermal energy and solar energy. However, the application of these energy sources is highly susceptible to weather, season, location, and time. Thus, these alternative energies are unstable, random, fluctuating, intermittent, and inefficient. The development of energy storage technologies can efficiently solve these problems, storing and releasing energy when needed. Among the key materials used in various energy-storage technologies, phase-change materials (PCMs) are strong candidates for

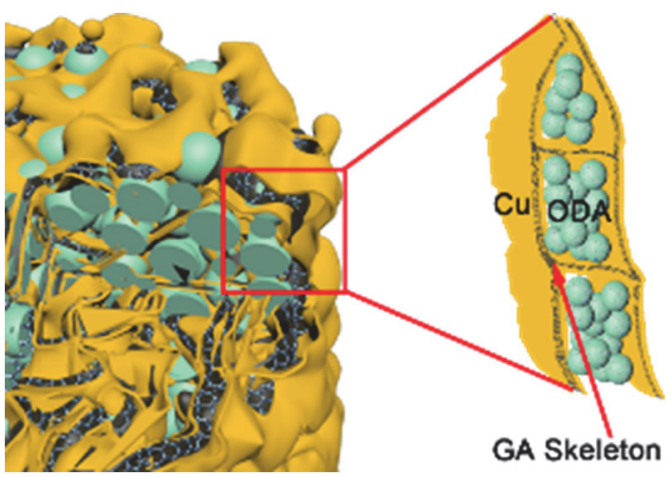
smart thermal energy management and portable thermal energy sectors. As most innate PCMs face issues of low thermal conductivity, environmental pollution, and leakage over their melting point, encapsulating PCMs into supporting materials is necessary. However, these supporting materials face significant challenges in their application. First, skeleton materials should be resistant to the PCM volume changes during melting and solidification processes to achieve suitable structural stability. Second, skeleton materials should also have high thermal conductivity and a low leakage rate. Graphene aerogel (GA) has proven to be an effective supporting skeleton to improve the shape-stability of PCMs; however, the leakage caused by the phase transition and the brittleness of the network structure is a primary problem restricting its application. Skeleton materials play a crucial role in the performance of PCMs. Herein, we propose a double-pulse plating reinforcement strategy for fabricating copper@graphene aerogel (Cu@GA) as a skeleton material for phase change energy. In this design, individual nanosheets of the GA were uniformly covered and interlinked by copper particles. The Cu@GA interlinked networks ensure suitable thermal conductivity and a robust framework, beneficial for phase change heat transfer and leaksuppression performance. In addition, we prepared a PCM composite with high structural stability and low leakage rate by encapsulating octadecylamine (ODA) in Cu@GA through vacuum impregnation to ensure homogeneous ODA dispersion in the $\mathrm{Cu} @ G A$ porous structure. The influence of different skeletons on the PCM composite leakage rate was investigated by comparing the weight change of the PCM composite. Benefiting from these structural features, the optimized composite phase change material (CPCM) Cu@GA/ODA showed a reduced leakage rate of $19.82 \%$ ( $w$, mass fraction) compared to $80.31 \%(w)$ of GA/ODA and $72.99 \%(w)$ of GOA/ODA after 20 heat storage and release cycles. The cycled skeleton morphology was investigated using scanning electron microscopy to determine the origin of this influence. The skeleton
\end{abstract}

Received: December 31, 2020; Revised: February 15, 2021; Accepted: February 18, 2021; Published online: February 25, 2021.

${ }^{*}$ Corresponding author. Email: ccm@sxicc.ac.cn; Tel.: +86-351-404-9061.

†These authors contributed equally to this work.

The project was supported by the National Natural Science Foundation of China (21922815, 51802325), the Natural Science Foundation of Shanxi Province (201901D211585), the Scientific and Technological Key Project of Shanxi Province (20191102003), the Patent Promotion and Implementation Project of Shanxi Province (20200716) and the Key Research and Development (R\&D) Projects of Shanxi Province (201903D121007).

国家自然科学基金(21922815, 51802325), 山西省自然科学基金(201901D211585), 山西省科技攻关专项(20191102003), 山西省专利推广实施资助专项 (20200716)和山西省重点研发项目(201903D121007)资助

(C) Editorial office of Acta Physico-Chimica Sinica 
integrity of Cu@GA/ODA was well maintained, while the three-dimensional network structures of GOA/ODA and GA/ODA showed shrinkage or collapse. Thus, the copper coating increased the skeleton's microstructural stability, conducive to high structural stability and reducing the leakage rate of the PCM composite. This study paves the way for the construction of ideal metal-coating GA composites with an excellent comprehensive performance for future phase change energy storage, porous microwave absorption, and energy storage applications.

Key Words: Electroplating; Copper@graphene aerogel; 3D graphene skeleton; Phase change material; Friability

\title{
高结构稳定性、低泄漏率三维铜@石墨烯复合相变材料的制备
}

\author{
李晓明 $1,+$, 高逸丹 $1, \dagger$, 孔庆强 ${ }^{1}$, 谢莉婧 ${ }^{1}$, 刘卓 ${ }^{1}$, 郭晓倩 ${ }^{1}$, 刘燕珍 ${ }^{1}$, 卫贤贤 ${ }^{3}$, \\ 杨晓 ${ }^{1}$, 张兴华 1 , 陈成猛 1,2 , \\ 1 中国科学院山西煤炭化学研究所, 中国科学院炭材料重点实验室, 太原 030001 \\ 2 中国科学院大学材料科学与光电技术学院, 北京 100049 \\ ${ }^{3}$ 太原科技大学环境与安全学院, 太原 030024
}

摘要: 由于能源消费需求的持续增长和传统化学燃料的日益枯竭, 对可再生能源的需求日益迫切。以地热能、太阳能为 代表的可再生能源脱颖而出。然而, 这些能源的应用易受到天气、季节、地点和时间的影响, 具有不稳定性、随机性、 波动性和间歇性。储能技术是解决上述问题的有效途径, 它可以在需要的时候储存或释放能量。在各种储能技术可选材 料中, 相变材料(PCMs)是智能热能管理和便携式热能领域的有力候选者。大多数相变材料都存在导热系数低、环境污 染、熔点泄漏等问题, 因此有必要将相变材料封装到支撑骨架材料中。事实上, 支撑材料在应用中仍面临着一些重大挑 战。首先, 骨架材料应能抵抗相变材料在相变过程中的体积变化, 即具有良好的结构稳定性。其次, 还应具有较高的导 热系数和较低的泄漏率。石墨烯气凝胶(GA)已被证明是提高相变材料形状稳定性的有效支撑骨架, 但相变引起的泄漏和 网络结构的脆性是制约其应用的关键问题。在此, 我们提出了一种双脉冲电镀的强化策略, 用于制备铜@石墨烯气凝胶 (Cu@GA)作为相变储能骨架材料。这一结构设计中, 石墨烯气凝胶上的石墨烯片层上均匀地镀上了铜层, 且不同片之间 被铜镀层所连接。这种铜增强石墨烯气凝胶网络结构赋予复合材料良好的导热性和坚固的骨架稳定性, 有利于增强相变 换热和抑制相变过程中的泄漏。此外, 通过真空浸渍法将十八胺(ODA)封装在Cu@GA骨架中, 获得了结构稳定性高、泄 漏率低的复合相变材料(Cu@GA/ODA), 保证了ODA在Cu@GA骨架材料中的均匀分散和填充。通过比较复合相变材料 的重量变化, 研究了不同骨架对复合相变材料泄漏率的影响。优化后的复合相变材料(CPCM)Cu@GA/ODA经20次储热、 放热循环后, 泄漏率降低至 $19.82 \%$ ( $w$, 质量分数), 而GA/ODA和GOA/ODA为骨架的复合相变材料的泄漏率分别为 80.31\% (w) 和 $72.99 \%(w)$ 。为了探讨这种影响的原因, 用扫描电子显微镜(SEM)观察了循环后骨架的形貌。铜/石墨烯气 凝胶(Cu@GA)骨架材料没有明显的收缩或坞塌, 仍可以保持完整的三维网络结构, 而氧化石墨烯气凝胶(GOA)和石墨烯 气凝胶 $(G A)$ 的骨架材料三维结构不复存在, 且在氧化石墨烯/石墨烯片能够观察到明显的裂隙。铜涂层可以提高骨架的 微观结构稳定性, 有利于提高结构稳定性, 降低复合材料的泄漏率。同时, 该研究为构建理想的金属增强石墨烯气凝胶 复合骨架材料铺平了新的道路, 该复合材料具有优异的综合性能, 可用于未来的相变储能、多孔微波吸收和储能应用。

关键词: 电镀; 铜/石墨烯气凝胶; 三维石墨烯骨架; 相变材料; 脆性 中图分类号：0642

\section{Introduction}

Phase change energy storage is a valid and useful strategy for thermal energy storage ${ }^{1}$, which relies on the latent heat of phase change materials (PCMs) to store and/or release heat. PCMs can effectively solve the intermittency, randomness and instability issue of renewable energy e.g., solar energy ${ }^{2,3}$. Furthermore, PCMs are utilized as a thermal buffer in power vehicles, microelectronic devices and building application, as well as off- peak electricity storage systems ${ }^{4}$. However, wide applications of PCMs are hindered by their intrinsic low thermal conductivity, obvious leakage and large volume change in the process of phase process 5 .

Commonly, PCMs are encapsulated into hard shells or integrated with high thermal conductive fillers to upgrade thermal conductivity for PCMs. But it's difficult to establish high efficiency thermal conductivity network due to the interfacial 
thermal resistance between shells and fillers ${ }^{6-8}$. Threedimensional (3D) network skeleton, due to high surface area, good electric and heat conductivity, is identified as a promising support material to overcome the limitations of interfacial thermal resistance of discrete, fragmentary nanoshells or fillers. Various architectures ${ }^{9-16}$ such as graphene aerogel (GA) ${ }^{17}$, MOFs ${ }^{18}$, porous polymer ${ }^{5,19}$, carbon foam ${ }^{20-22}$ and BN-based porous scaffolds ${ }^{23,24}$, can not only encapsulate the PCMs but also enhance thermal conductivity. However, the leakage is still unavoidable. One probable reason for this issue could be the poor interface adhesive strength between PCMs and skeleton ${ }^{24-26}$; the other is the poor structure stability resulting from huge volume change during the solid-liquid phase change process. Compared to other 3D skeletons, three-dimensional (3D) graphene aerogel (GA) ${ }^{27}$, due to high surface area, good electric and heat conductivity, as well as shape stability at extremely low density ${ }^{28,29}$, is regarded as a desired matrix material. In 2013, Zhong et al. ${ }^{30}$ first introduced the GA as support material into PCM. The capillary force of interconnected pores of GA prevented effectively the seepage of octadecanoic acid. In order to further improve the shape-stability, the rational hybridization of fibers ${ }^{3,6,31}$ and sheet materials ${ }^{24,25,32}$ together with GA has attracted increasingly attention in recent years. The thermal conductivity and stability of composite PCMs have been remarkably enhanced owing to the full inherited advantages of the component materials and their interconnected carbon skeleton. Unfortunately, the interspersed multiphase structure will generate large quantities of interface defects which will disrupt the integrity of the formed aerogel and lead to the leakage problem ${ }^{33-35}$. Therefore, further improvement of the graphene aerogel matrix is needed to achieve higher structure integrity of PCMs and better thermal properties.

It is an effective strategy to prepare graphene aerogel composites using coating materials with thermal conductivity and ductility. It will be of benefit to improve heat uniformity, reduction of structural brittleness and invigorate shape stability. It is generally known that copper with excellent ductility and good electrical/thermal conductivity is an ideal reinforcement component candidate ${ }^{36,37}$. Therefore, the fabrication of GA composite, using GA as skeleton material and copper as reinforcing material, is regarded as a novel and efficient strategy.

This work, a series of 3D copper@graphene composites ( $\mathrm{Cu} @ \mathrm{GAs})$ were designed and fabricated by simple but efficient electroplating strategy and used in the encapsulation of octadecylamine (ODA) (Fig. S1, see Supporting Information). The as-prepared $\mathrm{Cu} @$ GAs were expected to get a new kind of skeleton material with excellent properties. Firstly, graphene oxide aerogels (GOAs) were constructed by sol-gel method, and then graphene aerogels (GAs) were obtained by annealing GOAs at $1500{ }^{\circ} \mathrm{C}$ for $60 \mathrm{~min}$ under $\mathrm{Ar}$ atmosphere. Afterwards, copper atoms were deposited on the surface of GAs under the electric field by electroplating, and then $\mathrm{Cu} @$ GAs were obtained. The as-prepared 3D $\mathrm{Cu} @$ GAs show highly-interconnected microstructure, high strength, superior electrical/thermal conductivity and shape stability. The copper coating is compatible with octadecylamine (ODA), and provides a good balance between thermal conductivity and strength.

\section{Experimental}

\subsection{Reagents}

In this work, all reagents were analytical grade and used without further purification. Graphite powders with an average size of 325 mesh were purchased from Sinopharm Chemical Reagent Co., Ltd. $\mathrm{KMnO}_{4}, \mathrm{NaNO}_{3}, \mathrm{H}_{2} \mathrm{SO}_{4}$ and ethanediamine (EDA) were purchased from Tianjin Tianli Chemical Reagents Co., Ltd. $\mathrm{CuSO}_{4} \cdot 5 \mathrm{H}_{2} \mathrm{O}$ and octadecylamine (ODA) were purchased from Shanghai Aladdin Bio-Chem Technology Co., Ltd.

\subsection{The preparation of graphene aerogel}

Graphene oxide solution was prepared by modified Hummers' from original graphite ${ }^{38}$. The preparation of graphene aerogel was referred to the method of Qiu et al. ${ }^{39}$. EDA was selected as reducing and cross-linking agent, and graphene oxide solution as basic building block. $20 \mu \mathrm{L}$ EDA was dropped into $5 \mathrm{~mL}$ graphene oxide solution $\left(3 \mathrm{mg} \cdot \mathrm{mL}^{-1}\right)$, and the mixture was violently shaken for a few seconds. Graphene oxide aerogel (GOA) was obtained by heating the mixture in a glass bottle at $95^{\circ} \mathrm{C}$ for $6 \mathrm{~h}$, then followed by freeze-drying for $48 \mathrm{~h}$. GOA was further annealed in a corundum tube at $1500^{\circ} \mathrm{C}$ for $60 \mathrm{~min}$ at the temperature increase rate of $5{ }^{\circ} \mathrm{C} \cdot \mathrm{min}^{-1}$ under flowing $\mathrm{Ar}$ atmosphere, marked as graphene aerogel (GA) so that any residual oxygen in the graphene is reduced.

\subsection{Cu-coated graphene aerogel}

Electroplating method was used to coat $\mathrm{Cu}$ on the surface of graphene aerogel. Double pulse electroplating power source (SMD-30) was used to supply power. It was periodic reverse pulse current with pulse both in positive and negative direction. The electrical forward current was kept at $0.1 \mathrm{~A}$, and reverse current at $0.01 \mathrm{~A}$. Thereinto, the forward current was run for duration $100 \mathrm{~ms}$, while the reverse current was $10 \mathrm{~ms}$. 0.16 $\mathrm{mol} \cdot \mathrm{L}^{-1} \mathrm{CuSO}_{4}$ worked as electrolyte, graphene aerogel (GA) as cathode and copper film as anode to electrochemical cell. After electroplating for 10, 20,30 and $40 \mathrm{~min}$, GAs were covered by a bright orange-red coating, and we named the $\mathrm{Cu}$ coated GAs as $\mathrm{Cu} @$ GAn (n represents the corresponded electroplating time).

\subsection{Preparation of PCM composites}

The as-obtained samples (GOA, GA, Cu@GA40) were immersed in heated and melted octadecylamine (ODA) via a vacuum impregnation process. First, the ODA was heated in vacuum oven at a constant temperature of $65^{\circ} \mathrm{C}$ for $30 \mathrm{~min}$ in a beaker to make sure it melts. Then, GOA, GA and Cu@GA40 were impregnated into molten ODA in vacuum oven at $65^{\circ} \mathrm{C}$ for another $2 \mathrm{~h}$ to remove bubbles inside and ensure impregnation ODA into the 3D framework perfectly. Finally, removed, cooled and solid naturally, the composite phase change materials (CPCMs) were obtained. Samples were denoted as GOA/ODA, 
GA/ODA and $\mathrm{Cu} @$ GA/ODA, respectively.

\subsection{Characterization}

The micro morphology and crystal structure of as-prepared samples were characterized by scanning electron microscope (SEM, JSM-7001F, Japan Electronics Co., Ltd.), energy disperse X-ray spectroscopy (EDX, QX200, Bruker Corporation), transmission electron microscope (TEM, JEM-2100F, Japan Electronics Co., Ltd.), and X-ray diffraction (XRD, bruker D2 phaser desktop, Bruker Corporation). The chemical structure of the samples was characterized by Fourier Transform Infrared Spectroscopy (Nicolet 380, Thermo Fisher Scientific) at a spectral range of $500-4000 \mathrm{~cm}^{-1}$.

The electrical property was determined by digital multimeter according to four-probe principle, in which two wires were extracted and connected with the samples (VC480C+, Shenzhen Vicimeter Technology CO., Ltd.). Mechanical property was measured by universal material experiment machine (HK-318, Huakai test). Thermal conductivity was identified by Hot-Disk thermal analysis technology (Hot-Disk, Swedish Hot Disk Co., Ltd.). The thermal decomposition and shape-stability of pure ODA and CPCMs were tested in the temperature range of $40{ }^{\circ} \mathrm{C}$ to $700{ }^{\circ} \mathrm{C}$ by a thermogravimetric analyzer (TGA, TGA2, METTLER TOLEDO.). And macroscopic shape-stability was performed by digital photographs ulteriorly, which is similar approach as reported by Yang et al. ${ }^{40}$. In addition, the mass change of pure ODA and CPCMs before and after heating at $80{ }^{\circ} \mathrm{C}$ (above the melting point of ODA) for $30 \mathrm{~min}$ was used to evaluate the leakage rate. This similar method was reported by Zhao et al. ${ }^{41}$ and Tian et al. ${ }^{42}$, for more detailed testing information, see the supporting information. The infrared camera (FLUKE Ti32, USA) was used to observe the heat transfer capability and temperature distribution of the samples in heating processes.

\section{Results and discussion}

In order to obtain a uniformly distributed copper coating on both the inside and outside surface of GA, the double pulse electroplating power was used as electroplate power supply, the mechanism of plating as shown in Fig. S2.

\subsection{Characterization of the prepared GOA, GA and Cu@GAs}

As displayed in Fig. 1a-d, SEM was employed to investigate the morphologies of samples. GOA showed a typical 3D crosslinked network structure, with pore size ranging from hundreds of nanometers to ten microns (Fig. 1a). After carbonization, the pore diameter was enlarged, and the graphene sheet became more flat (Figs. 1b and S3). As a result of electroplate, copper particles were attached on the surface of graphene sheets. The $\mathrm{Cu} @$ GA maintains its porous structure as shown in Figs. 1c and S4. From this interconnected porous structure $\mathrm{Cu} @$ GA act as a skeleton material and can encapsulate the ODA into the porous structure efficaciously. The SEM and EDX elemental mapping in Fig. S5 showed the morphology and chemical composition of $\mathrm{Cu} @$ GA after electroplating $10 \mathrm{~min}$, respectively. The equally distributed copper particles were observed in the elemental mapping, indicating that the copper particles were homogeneously attached to the surface of graphene sheet. The signature peaks corresponded to $\mathrm{C}, \mathrm{O}$ and $\mathrm{Cu}$ were observed evidently and the weight percentage of $\mathrm{C}, \mathrm{O}$ and $\mathrm{Cu}$ were $66.32 \%, 2.62 \%$ and $31.06 \%$, respectively. $\mathrm{Cu}$ had a strong peak, showing that copper layer deposited homogeneously and firmly combined with the graphene sheets (Fig. S5). Furthermore, EDS line to scan profile confirmed the even distribution of $\mathrm{Cu}$ on the surface of graphene sheets as shown in Fig. S6. The aggregate composed of nano-copper particles appears on the copper layer which thickens gradually with the passage of time. Besides, as the electroplating time increased, the copper particles grew
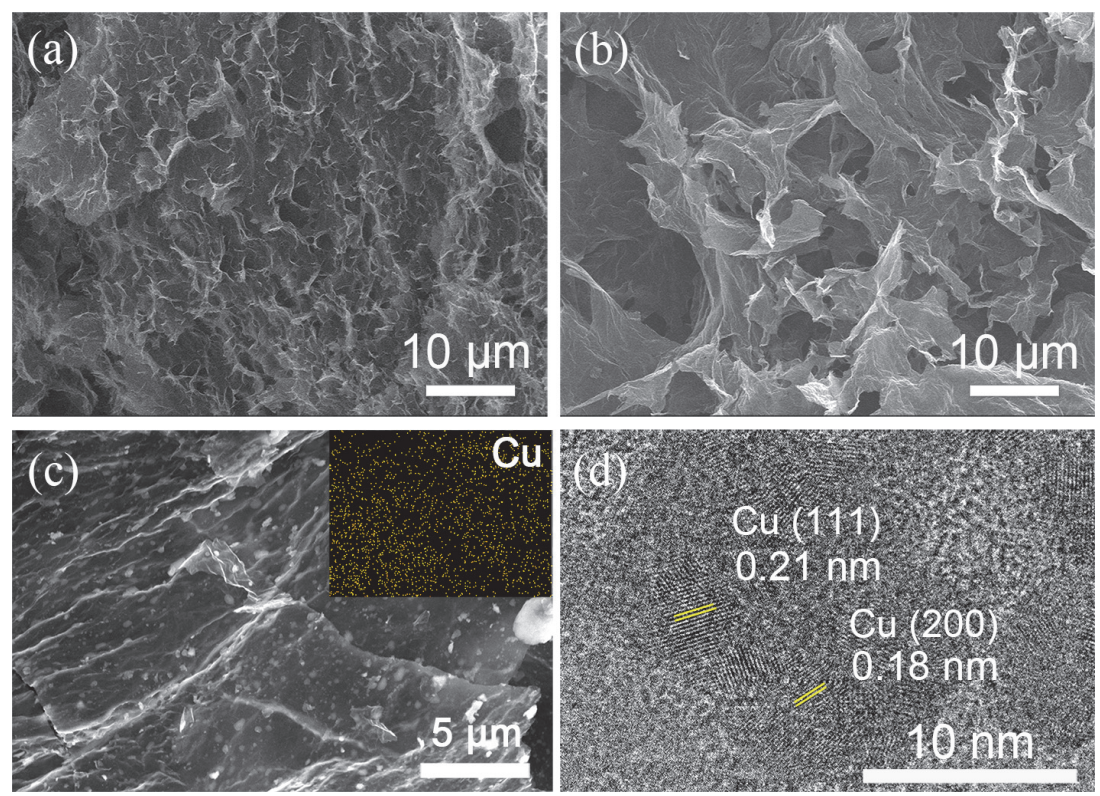

Fig. 1 The SEM images of a) GOA, b) GA, c) Cu@GA40 and with the corresponded Cu elemental distribution mapping images;

d) HR-TEM images of $\mathrm{Cu} @$ GA-40. 
larger as well (as shown in Fig. S7a-d). Some $\mathrm{Cu}$ particles growth and aggregation filled the whole clearance to realize the connection between different graphene sheets (Fig. S8c). The other $\mathrm{Cu}$ particles oriented growth in cave of $\mathrm{Cu} @ \mathrm{GA}$, or formed a 'bridge' structure between the corresponding inside walls or during one graphene sheet to the other graphene sheet as shown in Fig. S8b,d. And the latter helped to form a linking structure among disconnected graphene sheets. This interconnection microstructural is expected to greatly enhance the electrical and thermal conductivity network, and strengthened the mechanical property ${ }^{43}$.

The high transmission electron microscopy analysis was further adopted to characterize the micro-structure of asprepared Cu@GA40. As shown in Fig. 1d, high-resolution TEM (HR-TEM) revealed the characteristic lattice fringes to (111) and (200) of $\mathrm{Cu}$. Interlayer space of $0.21 \mathrm{~nm}$ was assigned to the (111) plane. And the interlayer space of $0.18 \mathrm{~nm}$ was assigned to the (200) plane of $\mathrm{Cu}$.

The crystal structures of GOA, GA and $\mathrm{Cu} @$ GA40 were demonstrated by XRD as shown in Fig. 2. It showed that the characteristic diffraction peaks of copper at $42.6^{\circ}$ and $49.8^{\circ}$ were (111) and (200) crystal planes, respectively. This indicated that the copper crystal was formed in face-centered cubic structure. The crystalline interplanar spacings were 0.21 and $0.18 \mathrm{~nm}$, corresponding to (111) and (222) separately calculated by Scherrer's formula, which were in consistent with the result of TEM (Fig. 1d). With the prolonged electroplating time, the intensity of copper diffraction peaks increased due to the aggregation of small copper particles in the pore of $\mathrm{Cu} @$ GA. The copper content in composite aerogel increased rapidly to $80 \%(w)$ at the first $10 \mathrm{~min}$, whereas merely $13.5 \%(w)$ increases was obtained at the next $30 \mathrm{~min}$ (Fig. S9).

Fig. S10 shows the FTIR spectra of the GOA and GA. The spectra of both GOA and GA show the $3439 \mathrm{~cm}^{-1}$ was associated to $\mathrm{O}-\mathrm{H}$ stretching vibrations, the $\mathrm{C}-\mathrm{H}$ stretching vibration from methyl and methylene groups is presented at 2924, 2854 $\mathrm{cm}^{-1}$. The band at $1645 \mathrm{~cm}^{-1}$ belongs to the $\mathrm{C}=\mathrm{O}$ stretching vibration, whereas the peak at $1401 \mathrm{~cm}^{-1}$ is due to the stretching vibrations of phenolic hydroxyl group. The absorption peak at nearly $1094 \mathrm{~cm}^{-1}$ is attributed to $\mathrm{C}-\mathrm{O}$ stretching vibration, the

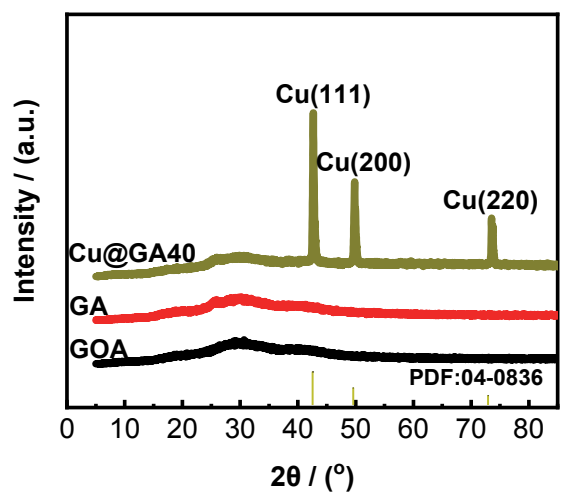

Fig. 2 XRD patterns of GOA, GA and Cu@GA40. peak at $667 \mathrm{~cm}^{-1}$ is due to the in-plane rocking vibration of methyl. These characteristic peaks include $\mathrm{C}-\mathrm{O}$, and phenolic $\mathrm{O}-\mathrm{H}$ weaken and the $\mathrm{C}-\mathrm{O}$ vibration of GOA are centered at $1094 \mathrm{~cm}^{-1}$ shifts to $1043 \mathrm{~cm}^{-1}$ after heat treatment ${ }^{44}$. This indicates the content of oxygen containing functional groups were reduced, and implies that the GA is successfully formed by heat treatment.

Fig. 3a shows that the electrical conductivity $(\rho)$ of GOA was approach zero. While the electrical conductivity of GA was increased to $0.329 \mathrm{~S} \mathrm{~cm}^{-1}$ after thermal reduction process, due to the removal of the oxygen atoms and recovery of $\pi-\pi$ bonding in graphene sheets ${ }^{45}$. Furthermore, the electrical conductivity of Cu@GA40 reached to $11.9 \mathrm{~S} \cdot \mathrm{cm}^{-1}$. This indicates that the electrical conductivity significantly improvement by copper coating. The electrical conductivities of GOA, GA and $\mathrm{Cu} @$ GA40 were indirectly displayed according to the light of LED lamps (Fig. 2b-d). There was nearly no light for GOA, indicating the highest resistance, the light of GA was bright, and it became glaring for $\mathrm{Cu} @$ GA40. That is to say, when aerogel as a conductor the LED lamp light of with increased copper content became brighter and brighter. The phenomenon was in accordance with the electrical conductivity measured by digital multimeter. The remarkable enhancement of electrical conductivity was attributed to uniform copper layer on the inner and outer surface of aerogel. Besides, the copper layer filled defects and built up the electrical conductivity networks in GA (as seen in Fig. S8). The networks can shorten the electronic transmission path, resulting in electrons passed relatively unimpeded through aerogel.

Heat transfer in carbon materials not only resulted from the acoustic phonons, but also the electronic contributions. While for metal, thermal conductivity $(\kappa)$ mainly depended on the free carry concentration, leaving the contribution of phonons limited to $1 \%-2 \%$ of the total ${ }^{46}$. Fig. 3 a shows that the thermal conductivity of GOA was as low as $0.035 \mathrm{~W} \cdot \mathrm{m}^{-1} \cdot \mathrm{K}^{-1}$ due to the existence of oxygen groups in graphene oxide sheets, which acted as barriers for phonon conduction. For GAs, besides the phonon-transport regime, its thermal conductive was related to the scattering and leakage of phonon at the interfaces. After the

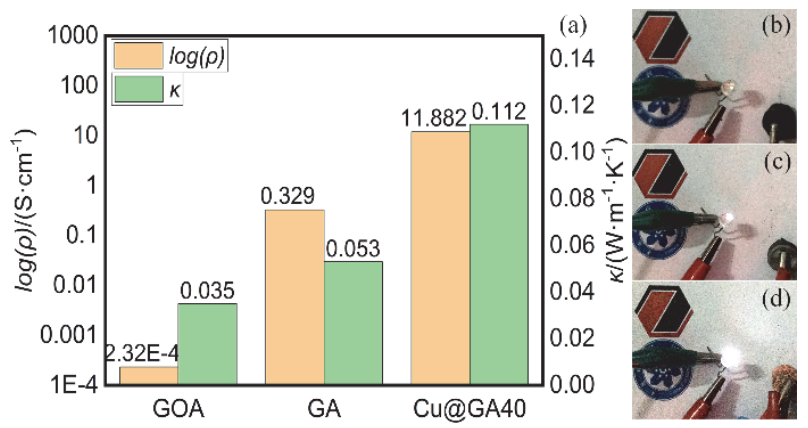

Fig. 3 a) The electrical conductivity $(\rho)$ and the thermal conductivity ( $\kappa$ ) of GOA, GA and Cu@GAs. Demonstration of the electrical conductivity of b) GOA, c) GA and d) Cu@GA40 by brightness of LED lights. 
reduction, the oxygen atoms on graphene sheet surface were removed, and the graphitic lattice will be "self-healing" ${ }^{38}$. So the phonon group velocity is much higher for restored graphene compared to unrestored graphene. Therefore, the thermal conductivity of samples increased from 0.035 to 0.053 $\mathrm{W} \cdot \mathrm{m}^{-1} \cdot \mathrm{K}^{-1}$ by thermal reduction, the results showed limited benefit here. After copper plating, the thermal conductivity of $\mathrm{Cu} @ \mathrm{GA} 40$ surged to $0.11 \mathrm{~W} \cdot \mathrm{m}^{-1} \cdot \mathrm{K}^{-1}$, and the electrical conductivity showed similar encouraging results. It can conclude that, the disparity of thermal conductivity between GA and $\mathrm{Cu} @$ GA stems from two aspects: on the one hand, by compact copper coating on the GA surface through copper plating, the edge imperfection and the gap of graphene sheets were repaired. It is helpful to form the in-plane heatwave front, which greatly reduces phonon scattering and leaking. And on the other hand, a new transmission mechanism, electrons conduct heat was introduced in $\mathrm{Cu} @$ GAs, which dependence on the number of copper on the graphene sheets. Both phonons and free electrons contributed to increase the thermal conductivity ${ }^{47}$. Thermal conductivity of multi-dimensional $\mathrm{Cu} @$ GAs can be described by Fourier's law: $q=-K \Delta T$, where $q$ is the heat flux, $K$ and $\Delta T$ are the thermal conductivity of material and the temperature gradient, respectively. For sample $\mathrm{Cu} @ \mathrm{GAs}$, heat is conducted by both phonons and electrons, so $K=K_{\mathrm{e}}+K_{\mathrm{p}}$, where $K_{\mathrm{e}}$ contribution comes from acoustic phonons of graphene, and $K_{\mathrm{p}}$ contribution comes from free carriers of copper. As shown in Fig. 3a, indeed, copper coating enhanced the thermal conductivity of the $\mathrm{Cu} @$ GA40, and which is 230-fold than GA. The high thermal conductivity may hopefully expedite the melting/solidifying process and improve the rate of energy storage process.

Besides the electrical and thermal conductive, the frangibility of GA can be suppressed effectively by copper coating. Here, samples before and after electroplating were tested by a simple method. GOA, GA and $\mathrm{Cu} @$ GA were put on the adhesive tape at under same pressure, respectively (Fig. $4 \mathrm{a}-\mathrm{c}$ ). Then the aerogels were taken out from the tape after $60 \mathrm{~s}$ to observe the residue on the tape. As clearly shown in Fig. $4 d-f$, when the samples were removed, residual fragments were found on the tape for GOA (Fig. 4d) and GA (Fig. 4e), illustrating the bad mechanical strength, which are a common phenomenon for graphene based aerogel ${ }^{48}$. However, Cu@GA40 retained its shape integrity well, and no dreg was observed, owing to the protection of copper layer on its surface (Fig. 4f). This can be due to the dense copper coating layer forms an interconnected structural reinforcing mesh to avoid the brittle fracture of graphene aerogel under stress as show in Figs. S7 and S8. This offered a new route to solve the crumble problem of aerogel.

The compressive stress-strain curves were exploited to characterize the mechanical strength of GOA, GA and $\mathrm{Cu} @$ GAs, each sample was cylindrical with a diameter of $10 \mathrm{~mm}$ and a length of $11 \mathrm{~mm}$. The same conditions were used for all tests. Once $50 \%$ strain $(\varepsilon)$ was reached, the test immediately stopped.
It was impossible to make samples with perfectly neatly smooth faces and flat edges, due to the fracture properties and brittleness of the aerogel. Thus, in the earliest testing stages (under 5\% compressive strain) ${ }^{49}$, only part of the sample surface was exposed to the loading platen. In other words, only few parts of sample were directly contacting the loading platen. Therefore, the data greater than $5 \%$ strain could then be applied to study the mechanical behavior of aerogel in this study. As shown in Fig. 5, the stress of GA increased linearly with the strain, corresponding to the elastic deformation. Compressive stress-strain curves of $\mathrm{Cu} @$ GAs were different from that of GA, which exhibited a typical crescent-shape and showed three distinct deformation regions (Fig. S11) ${ }^{50}$. The first stage is the initial linear elastic region at $\varepsilon<10 \%$, and the samples gradually shrink, due to the bending of the cell walls formed by interconnected copper coating graphene sheets. The second stage was a relatively flat plateau region, due to the energy dissipation caused by the bucking of copper coating structures with plastic deformation. The third stage was the densification region at $\varepsilon>45 \%$. Due to the fact that the densification of cells and continuously decreasing pore volume, the stress increased quickly with compression. Further increasing the stress, the 3D cross-linkage network of graphene sheets was destroyed along with the destruction of copper layer. Compared with GA, Cu@GA can endure more pressure under the same strain below $18 \%$. The $\mathrm{Cu} @ \mathrm{CA}$ can only stand limited pressure before its walls break. Once the pressure overload, walls and sheets of $\mathrm{Cu} @$ GA will undergo an irreversible deformation and fracture (Fig. S12). And this is why $\mathrm{Cu} @ \mathrm{CAs}$ have a narrower pressure change at the region of $45 \%>\varepsilon>18 \%$. Moreover, the hysteresis loop in

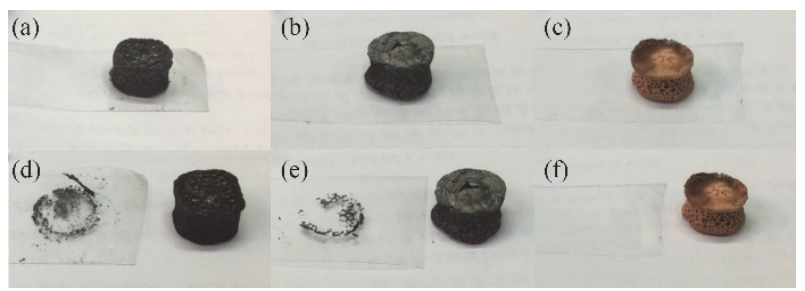

Fig. 4 Test of facial adhesive ability of GOA, GA and Cu@GA40. a) GOA, b) GA and c) CuGA were put on the tape. d) GOA, e) GA and f) $\mathrm{Cu} @ \mathrm{GA}$ were removed from the tape.

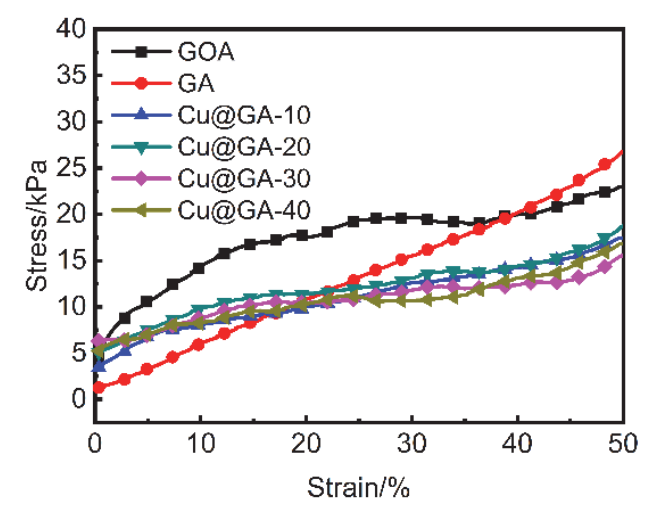

Fig. 5 The stress-strain test of GOA, GA and $\mathrm{Cu} @$ GAs. 


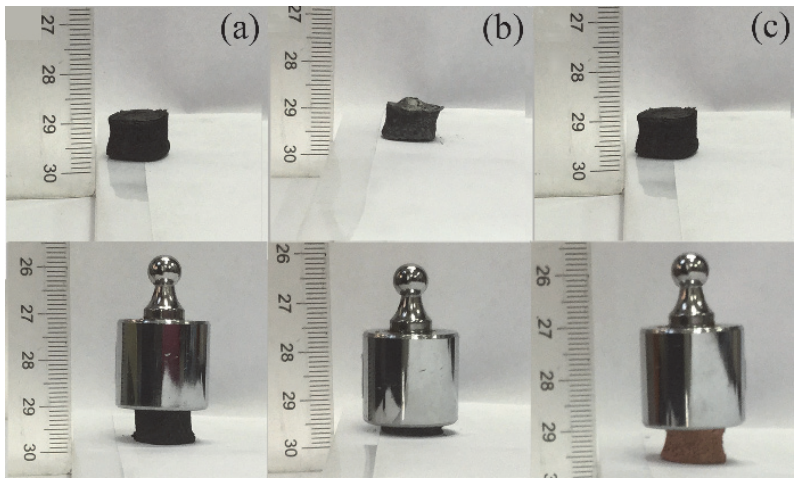

Fig. 6 The bearing ability of a) GOA, b) GA and c) Cu@GA40.

stress-strain curves of $\mathrm{Cu} @$ GAs were found to be broader compared with the GA. This meant that under same compressive stress, $\mathrm{Cu} @$ GAs could absorb more impact energy than GA (as see Fig. S11), and suffer greater stress. That means the 3D network structure of $\mathrm{Cu} @$ GAs can bear the greater impact and pressure that caused by the volume change during phase change process.

Moreover, we used the same weight (50 g) to compress aerogels. Remarkably, as shown in Fig. 6a-c, GOA and $\mathrm{Cu} @$ GA could completely sustain its original shape without any deformations and mechanical disruption under a load of at least 1000 times their own weight, while GA was compressed to nearly $25 \%$ of its original height. The result was in accordance with that of compressive stress-strain test. In other words, to optimize and upgrade the mechanical strength of graphene aerogel, electroplate strategy is an effective way to achieve it. For GA, graphene sheets interacted with each other to form cells, and these cells then ulteriorly connected to fabricate a honeycomb-like structure. This interesting structure has proven to be greatly beneficial to elastic modulus ${ }^{33,50,51}$. By contrast, $\mathrm{Cu} @$ GA with its composite structure tends to have great strength, as shown in SEM (Fig. S8) and ultrasound test (Fig. S13), copper particles can be strong adhesion on the graphene sheets, and fill the void among sheets, frame got up a 'bridge' between non-contact sheet. The centralized stress of $\mathrm{Cu} @$ GAs can be effectively decreased. It can form a reinforcement coating between graphene sheets, within the aerogel, or on the surface of cell walls.

\subsection{Properties of the composite PCM}

In order to further study the application effects as skeleton for phase change energy storage, octadecylamine was introduced into GO, GA and $\mathrm{Cu} @ \mathrm{GA} 40$ by vacuum impregnation, and then obtained phase change energy storage materials (PCMs).

The morphology of pure ODA and CPMs was observed by SEM as shown in Fig. 7. It is evident that, Pure ODA shown an irregular arrangement. While the ODA tightly attached to the surface of skeleton with the action of solidification and shrinkage, leading in clear directional streaks and grooves on the sample surface. There are obvious agglomeration of ODA on the surface of GOA and GA, but that has not happened on the surface of $\mathrm{Cu} @$ GA. The ODA was encapsulated effectively in the porous structure of the $\mathrm{Cu} @ \mathrm{G}$, and presented a regular arrangement. There was no obvious interface observed between the ODA and the skeleton, which revealed that ODA and $\mathrm{Cu}$ coating hold good compatibility and ODA can be absorbed and obliged by hole of $\mathrm{Cu} @$ GA. This is also supported by Figs. S14 and S15 and Tables S1 and S2 (Supporting Information). This can be very beneficial to restraining ODA leakage.

The FI-IT was also employed to understand the chemical
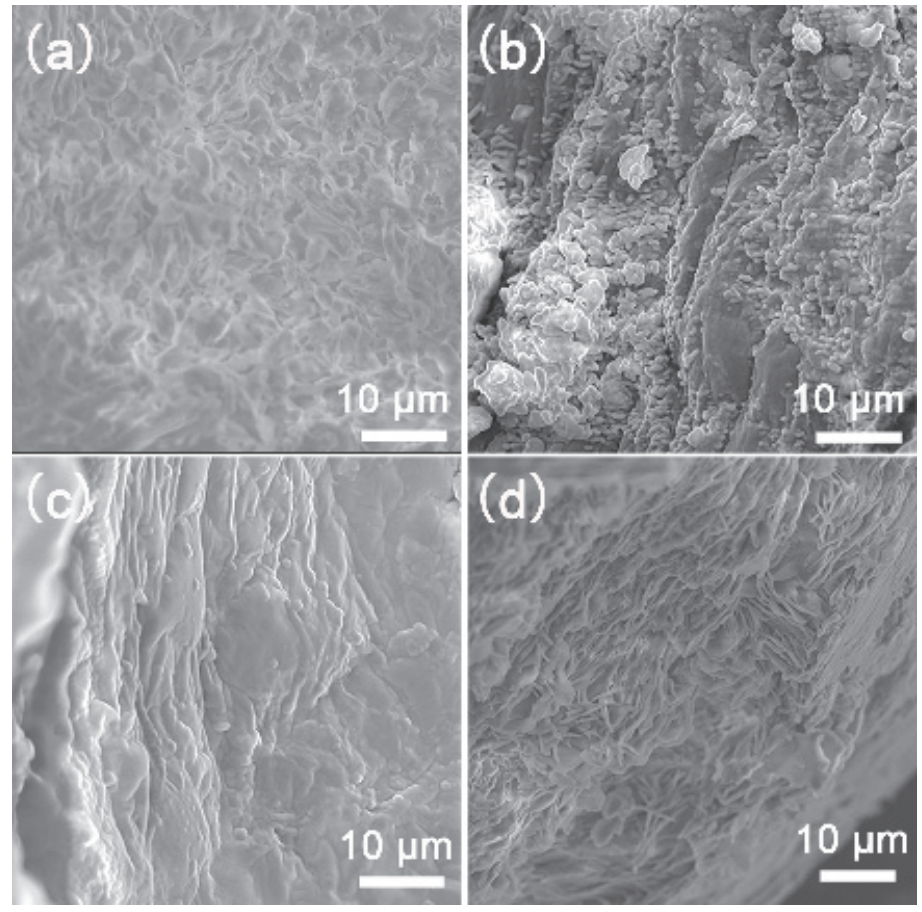

Fig. 7 SEM images of pure a) ODA, b) GOA/ODA, c) GA/ODA and d) Cu@GA/ODA. 
structure of CPCMs as shown in Fig. 8. A strong absorption peak of CPCMs is clearly observed at $3333 \mathrm{~cm}^{-1}$, which is attributed to the $\mathrm{N}-\mathrm{H}$ stretching vibration. Two characteristic absorption peaks were showed at $2917,2850 \mathrm{~cm}^{-1}$, the symmetrical stretching vibration and asymmetrical stretching vibration of continuous methylene groups $\left(\mathrm{C}-\mathrm{CH}_{2}-\mathrm{C}\right)$, respectively. The absorption peaks at $1462 \mathrm{~cm}^{-1}$ belongs to the scissoring vibration of $-\mathrm{CH}_{2}$. These new peaks appear only for the CPCMs, which are in good agreement with those appearing in the FT-IR of pure ODA. This implies that the composite PCMs are successfully prepared.

The thermogravimetric curves in Fig. 9 were employed to further assess the thermal reliability of the pure ODA, GOA/ODA, GA/ODA and $\mathrm{Cu} @$ GA/ODA composites. It is clear that no obvious pyrolysis occurs before at about $100{ }^{\circ} \mathrm{C}$. The pure ODA exhibit a single step weight loss, which begins at around $100{ }^{\circ} \mathrm{C}$ and completes at around $260{ }^{\circ} \mathrm{C}$. CPCMs are approximately same process, but have two stages. The results also showed that the starting gravimetric temperature of CPCMs lower than pure ODA, which may be due to high thermal conductivity of skeleton materials, but didn't affect its phase change application.

To comparison the thermal conductivity of the skeleton materials, and phase change behavior of ODA and CPCMs, we designed an experimental device. The samples were placed and

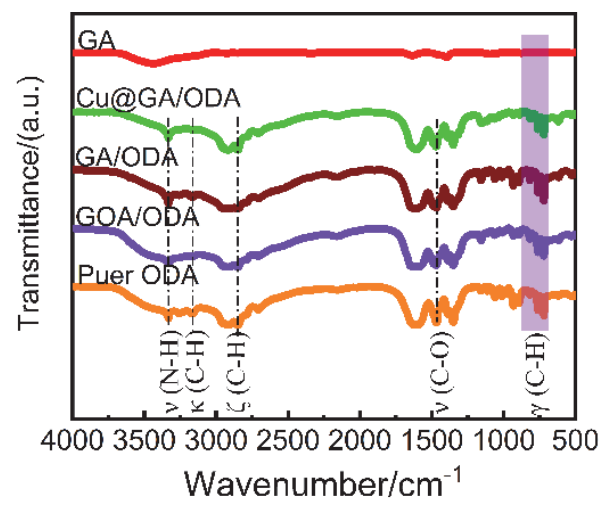

Fig. 8 FTIR spectra of the GA, pure ODA, GA/ODA, GA/ODA and Cu@GA/ODA.

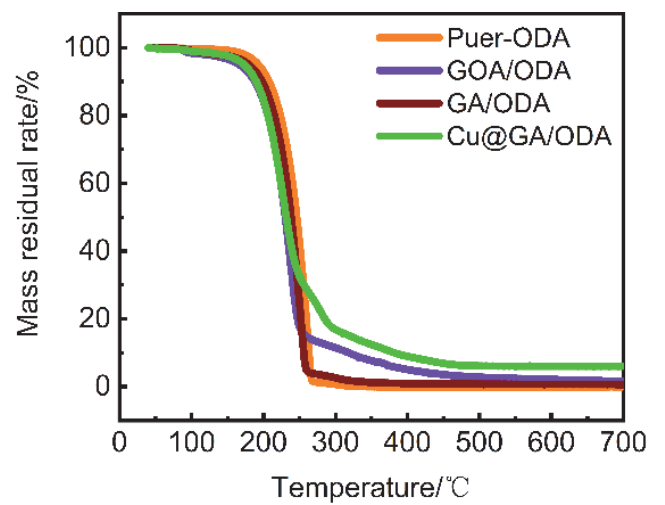

Fig. 9 Thermogravimetric curves of the pure ODA, GA/ODA, GA/ODA and Cu@GA/ODA. fixed on the surface of rapidly heated film by heat conductivity tape with high-temperature-resistant. The thermocouples (k-type punctiform thermocouple) were inserted into $2 \mathrm{~mm}$ below the top of cylindrical samples, thus minimize environmental impact during testing process. And thermocouples also were connected to a computer through a data collector. The whole test was implemented in a constant temperature room at $25^{\circ} \mathrm{C}$. Fig. S16 showed that the test device and schematic diagram. To prevent leakage of pure ODA above the melting point, the ODA was wrapped with preservative film. The heating film was rapidly heated from 25 to $70{ }^{\circ} \mathrm{C}$ within $30 \mathrm{~s}$. Once the temperature of one of the samples (thermocouple) achieved at $70^{\circ} \mathrm{C}$, and turn off the power of heating film promptly. Fig. 10 shows the temperature curves of ODA and CPCMs. It's obvious that $\mathrm{Cu} @ \mathrm{GA} / \mathrm{ODA}$ has the faster rate of heating and cooling process than other samples. Followed by GA/ODA and GOA/ODA, and pure ODA is the worst.

For PCM composites, the distributing condition of temperature and heat grads are crucial to its performance. Here, the heat grads and distribution in GOA/ODA, GA/ODA and $\mathrm{Cu} @ \mathrm{GA} / \mathrm{ODA}$ were demonstrated by infrared thermal imaging tests at a constant temperature of $80{ }^{\circ} \mathrm{C}$. It is evident from infrared thermal images in Fig. 11a that the hot-cold interface is advanced from bottom to top at various times. As can be seen from the Fig. 11, at the initial (30 s), all samples have inhomogeneous surface temperature field. $\mathrm{Cu} @$ GA/ODA has the fastest interface propels because of its effective thermal conductivity. After heating for $120 \mathrm{~s}$, the interface of $\mathrm{Cu} @$ GA/ODA was raised to the top and becomes ambiguous, and while the interfaces of GOA/ODA and GA/ODA were slightly superior to half of the height. To achieve the same surface temperature and temperature distribution, the required heating time for GOA/ODA and GA/ODA was significantly longer than that for the $\mathrm{Cu} @$ GA/ODA. $\mathrm{Cu} @$ GA/ODA has the fastest overall heating rate and the uniformity of temperature field distribution, but GOA/ODA and GA/ODA have low heating rate and inferior heat transfer. These results were consistent with the above thermal conductivity that $\mathrm{Cu@GA} \mathrm{has}$ the highest thermal conductivity.

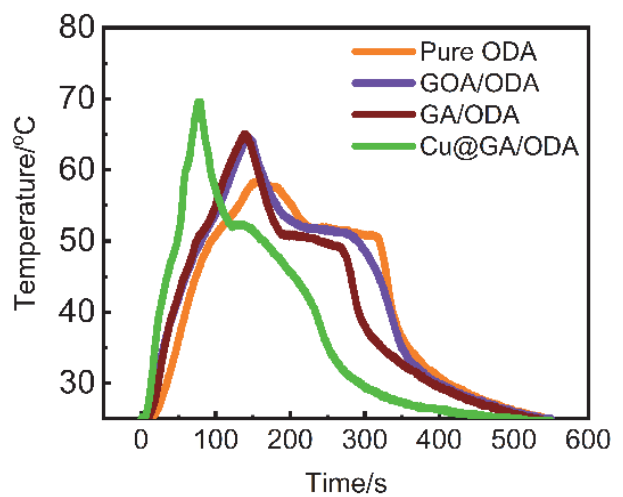

Fig. 10 The rise and drop rate curves of the GA, pure ODA, GA/ODA, GA/ODA and Cu@GA/ODA. 

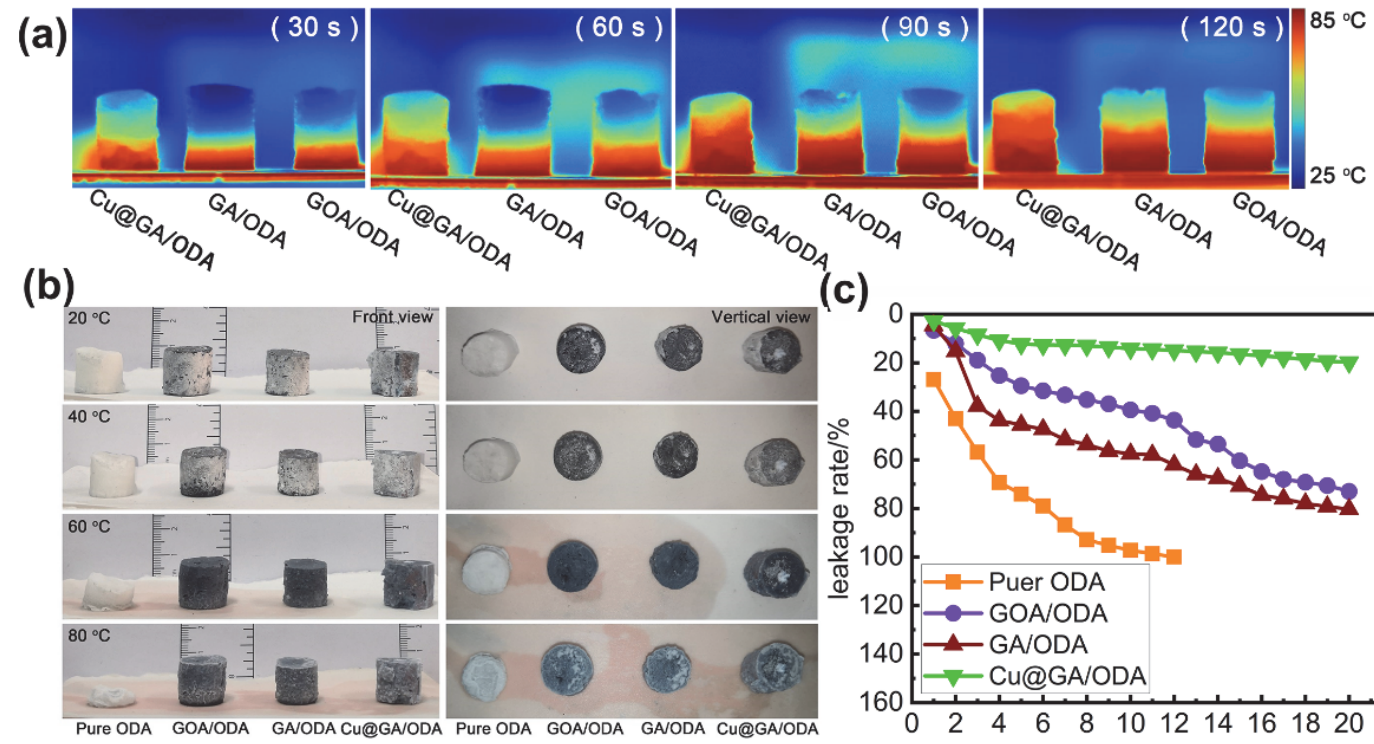

(c)

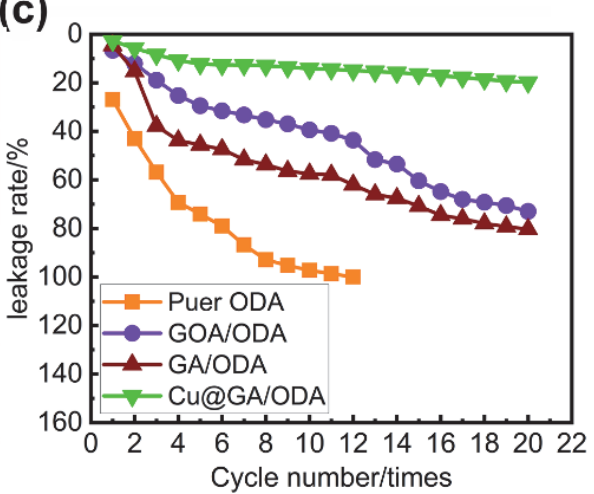

Fig. 11 a) Heat distribution and heat transfer properties of the CPCMs samples, b)Shape-stability test of pure ODA, GOA/ODA, GA/ODA and Cu@GA/ODA tracked by digital photography, c)rate of leakage curves of ODA, GOA/ODA, GA/ODA and Cu@GA/ODA during 20 cycles.

The shape-stability is an important parameter for preventing leakage of PCM, and provide reliable performance to practical application. Lack of shape-stability properties will cause the leakage of PCMs, which also to prejudice effect of the energy storage density of the composites. Thus, the shape stabilized performance of differently PCMs was tracked by digital photography, the pure ODA was used as the contrast sample. Samples were placed on filter papers and then heated in an oven at a series gradient temperature from 20 to $80^{\circ} \mathrm{C}$, and maintain there for $30 \mathrm{~min}$. As shown in Fig. 11b, all samples were solid with original shapes at both 20 and $40{ }^{\circ} \mathrm{C}$, below the melting point $\left(60^{\circ} \mathrm{C}\right)$ of ODA. When the temperature rises to $60^{\circ} \mathrm{C}$ and is maintained for $30 \mathrm{~min}$, half the pure ODA was lost through melting. GOA/ODA and GA/ODA can kept their shape, but filter papers under them were slightly wetted. By contrast, the $\mathrm{Cu} @$ GA/ODA maintained shape well and without any leakage. As the temperature further rising to $80{ }^{\circ} \mathrm{C}$, nearly a quarter of pure ODA was melted, and the liquid leakages of GOA/ODA, GA/ODA and Cu@GA/ODA were evident observed. We carried out further leakage test via measuring the weight change of the composite PCMs. Samples have different degrees of leakage as shown in Fig. 11b. After only 12 cycles, the ODA completely melts and disappears. However, after 20 cycles, the leakage rates of GOA/ODA and GA/ODA up to $72.9 \%(w)$ and $80.3 \%(w)$, respectively. This is just in a violent contrast with $\mathrm{Cu} @$ GA/ODA. No changed appreciably of $\mathrm{Cu} @$ GA/ODA was observed after maintaining at $80{ }^{\circ} \mathrm{C}$ for $30 \mathrm{~min}$. The leakage weight of $\mathrm{Cu} @$ GA/ODA just $2.7 \%$ (w) after first cycle. After 20 cycles, the ODA leakage of $\mathrm{Cu} @$ GA/ODA decreases from 2.7\% (w) to $0.3 \%(w)$, and the total leak rate was $19.8 \%(w)$. The results showed that the shape-stability of the composite $\mathrm{Cu} @ \mathrm{GA} / \mathrm{ODA}$ is superior to GOA/ODA, GA/ODA, pure ODA. The good shape-stability and the leakage-resistant performance can be attributed to the stronger capillarity force of $\mathrm{Cu} @ \mathrm{GA}$ skeleton to ODA and good interfacial affinity between ODA and copper ${ }^{52}$, which are effective for the incarceration of liquid ODA.

The samples after 20 cycles were immersed into excess absolute ethanol to dissolve the ODA which adsorbed on the surface of skeleton. Thus, the skeleton material of CPCMs was fully exposed. The morphology of the skeleton was characterized by scanning electron microscopy, which had suffered 20 cycles of phase change. During 20 times cycle processes, with melts and solidifies repeatedly of ODA, its volume expanding and contracting. As shown in Fig. 12, after 20 cycles, the 3D network wall of skeletons exhibited different microstructures. The networks of GOA/ODA and GA/ODA disappeared or collapsed and sheets of GOA/ODA and sheets integrity of GA/ODA damaged dramatically after 20 cycles, in the Fig. 12a,d,b,e, it can be seen clearly that there are distinct cracks of large sheets of GOA/ODA and GA/ODA. From the Fig. 12c,f, in sharp contrast, the Cu@GA/ODA still able to maintain its $3 \mathrm{D}$ porous network. This interesting phenomenon is considered to be the ductility and conductivity of copper attached to graphene sheets which can be confirmed by the SEM results as shown in Figs. S4 and S8. This microstructure effectively enhances the electrical/thermal conductivity and is beneficial to the strength properties of the skeleton.

Ordinarily, the skeleton occupy the workspace of CPCMs, which resulting in a decrease in the latent heat of the CPCMs. However, high enough energy storage density is a basic requirement of PCM. Thus, the phase-change properties of ODA, GOA/ODA, GA/ODA and $\mathrm{Cu} @$ GA/ODA were compared. The DSC curves of the melting and solidifying processes of the samples are presented in Fig. S17. As shown in Fig. S17 and Table S3, the energy storage efficiencies of ODA, 


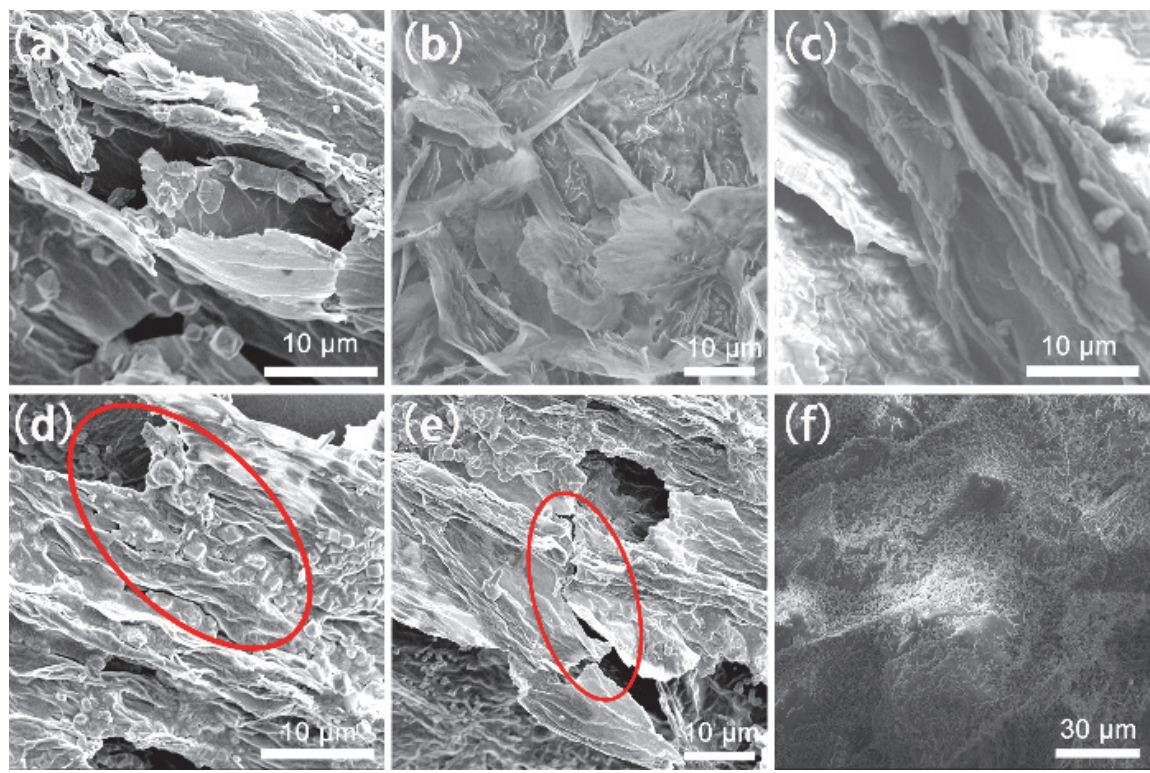

Fig. 12 SEM images of a) GOA, b) GA and c) $\mathrm{Cu} @$ GA and cross-sectional view of d) GOA, e) GA and f) Cu@GA after 20 cycles.

GOA/ODA, GA/ODA and $\mathrm{Cu} @$ GA/ODA are similar, indicating that $\mathrm{Cu}$ has little effect on the phase-change properties of CPCMs. Table S4. gives the thermal conductivity and the enthalpy loss rate of CPCMs. Compared with other skeleton materials, the enthalpy loss rate of phase change composite with $\mathrm{Cu} @$ GA skeleton is not significantly lower ${ }^{53-55}$. Furthermore, this sample had much better high structure stability, low leakage rate, and its melting and crystallization enthalpy can reach 220.00 and $218.83 \mathrm{~J} \cdot \mathrm{g}^{-1}$, respectively. In addition, the obtained $\mathrm{Cu} @$ GA/ODA possessed high latent heat as seen from Table S3. The highly thermally conductive of skeleton, $\mathrm{Cu} @$ GA, endowed the CPCM with quickly thermal response rates, resulting in a low melting temperature as shown in Fig. S17 and Table S3. This suggests that the copper attached on the graphene surface and connect the graphene sheets forms a porous structure of $\mathrm{Cu} @ \mathrm{GA}$, which provides a continuously thermally conductive channel for ODA.

\section{Conclusions}

In conclusion, electroplating, a traditional, but efficient method, was implemented for the preparation of versatile $\mathrm{Cu} @$ GAs with tunable structure. The crumble problem of GA was effectively solved by the protection of copper layer on the surface, which brought high compress modulus. In addition, $\mathrm{Cu} @$ GA showed high electrical and thermal conductivity after coating copper. The electrical conductivity of $\mathrm{Cu} @ \mathrm{GA}$ is two orders of magnitude higher than that of GA, from $0.329 \mathrm{~S} \cdot \mathrm{m}^{-1}$ of pure $\mathrm{GA}$ to $11.9 \mathrm{~S} \cdot \mathrm{m}^{-1}$ of $\mathrm{Cu} @ \mathrm{GA}$ after 40 min electroplating. And the thermal conductivity increased from $0.053 \mathrm{~W} \cdot \mathrm{m}^{-1} \cdot \mathrm{K}^{-1}$ to $0.112 \mathrm{~W} \cdot \mathrm{m}^{-1} \cdot \mathrm{K}^{-1}$, when the electroplating time increased from 0 to $40 \mathrm{~min}$. This was attributed into two factors: copper layer enhanced the channels, and reduced the resistance of the contacted graphene sheets. Therefore, it is desirable to deposit copper nanostructures on graphene sheets for the construction of a multifunctional GA. In addition, we encapsulating octadecylamine (ODA) into Cu@GA40 obtained a composite phase change material (PCM). The highly thermally conductive of skeleton, $\mathrm{Cu} @ \mathrm{GA}$, endowed the CPCM with quickly thermal response rates, resulting in a low melting temperature. The CPCM also showed satisfactory shape stability, high thermal conductivity, excellent resistance brittleness fracture and restrained spillages of liquid ODA above the melting point. After 20 cycles, the ODA accumulative total leakage rate of composite $\mathrm{Cu} @$ GA/ODA has been reduced to 19.82\% (w), compared with $80.31 \%(w)$ of GA/ODA and $72.99 \%(w)$ of GOA/ODA. Our present work may provide a potential strategy to develop commercial high-performance metals-based (such as $\mathrm{Ni}, \mathrm{Au}$, Ag, and Pt)@graphene composite aerogel for next-generation phase change energy storage, porous microwave-absorbing and energy storage, etc.

Supporting Information: available free of charge via the internet at http://www.whxb.pku.edu.cn.

\section{References}

(1) Li, M.; Mu, B. Y. Appl. Energy 2019, 242, 695. doi: 10.1016/j.apenergy.2019.03.085

(2) Gao, H. Y.; Wang, J. J.; Chen, X.; Wang, G.; Huang, X. B.; Li, A.; Dong, W. J. Nano Energy 2018, 53, 769. doi: 10.1016/j.nanoen.2018.09.007

(3) Chen, X.; Tang, Z. D.; Gao, H. Y.; Chen, S. Y.; Wang, G. iScience 2020, 23 (6), 101208. doi: 10.1016/j.isci.2020.101208

(4) Aftab, W.; Mahmood, A.; Guo, W. H.; Yousaf, M.; Tabassum, H.; Huang, X. Y.; Liang, Z. B.; Cao, A. Y.; Zou, R. Q. Energy Storage Mater. 2019, 20, 401. doi: 10.1016/j.ensm.2018.10.014

(5) Liao, H. H.; Chen, W. H.; Liu, Y.; Wang, Q. Compos. Sci. Technol. 
2020, 189, 108010. doi: 10.1016/j.compscitech.2020.108010

(6) Sheng, N.; Zhu, R. J.; Nomura, T.; Rao, Z. H.; Zhu, C. Y.; Aoki, Y.; Habazaki, H.; Akiyama, T. Sol. Energy Mater. Sol. Cells 2020, 206, 110280. doi: 10.1016/j.solmat.2019.110280

(7) Feng, Y. J.; Wang, J. P.; Liu, L. L.; Wang, X. D. Acta Phys.-Chim. Sin. 2019, 35 (6), 644. [冯英杰, 王进平, 刘丽丽, 王习东. 物理化学学 报, 2019, 35 (6), 644.] doi: 10.3866/PKU.WHXB201805068

(8) Nan, G. H.; Wang J. P.; Wang Y.; Wang H.; Li W.; Zhang X. X.. Acta Phys.-Chim. Sin. 2014, 30 (2), 338. [南光花, 王建平, 王艳, 王赫, 李伟, 张兴祥. 物理化学学报, 2014, 30 (2), 338.] doi: 10.3866/PKU.WHXB201312231

(9) Cheng, G.; Wang, X. Z.; He, Y. R. Appl. Therm. Eng. 2020, 178, 115560. doi: 10.1016/j.applthermaleng.2020.115560

(10) Cao, Y. F.; Fan, D. L.; Lin, S. H.; Mu, L. Y.; Ng, F. T. T.; Pan, Q. M. Chem. Eng. J. 2020, 389, 124318. doi: 10.1016/j.cej.2020.124318

(11) Qi, G. Q.; Yang, J.; Bao, R. Y.; Xia, D. Y.; Cao, M.; Yang, W.; Yang, M. B.; Wei, D. C. Nano Res. 2017, 10 (3), 802. doi: $10.1007 / \mathrm{s} 12274-016-1333-1$

(12) Khadiran, T.; Hussein, M. Z.; Zainal, Z.; Rusli, R. Energy 2015, 82, 468. doi: 10.1016/j.energy.2015.01.057

(13) Sobolciak, P.; Mrlík, M.; AlMaadeed, M. A.; Krupa, I. Thermochim. Acta 2015, 617, 111. doi: 10.1016/j.tca.2015.08.026

(14) Xiao, X.; Zhang, P.; Li, M. Appl. Energy 2013, 112, 1357. doi: 10.1016/j.apenergy.2013.04.050

(15) Zhang, P.; Meng, Z. N.; Zhu, H.; Wang, Y. L.; Peng, S. P. Appl. Energy 2017, 185, 1971. doi: 10.1016/j.apenergy.2015.10.075

(16) Karthik, M.; Faik, A.; D’Aguanno, B. Sol. Energy Mater. Sol. Cells 2017, 172, 324. doi: 10.1016/j.solmat.2017.08.004

(17) Li, G. Y.; Hong, G.; Dong, D. P.; Song, W. H.; Zhang, X. T. Adv. Mater. 2018, 30 (30), 1801754. doi: 10.1002/adma.201801754

(18) Gao, Z. Q.; Wang, C. Y.; Li, J. J.; Zhu, Y. T.; Zhang, Z. C.; Hu, W. P. Acta Phys.-Chim. Sin. 2021, 37 (7), 2010025. [高增强, 王聪勇, 李俊俊, 朱亚廷, 张志成, 胡文平. 物理化学学报, 2021, 37 (7), 2010025.] doi: 10.3866/PKU.WHXB202010025

(19) Xue, F.; Lu, Y.; Qi, X. D.; Yang, J. H.; Wang, Y. Chem. Eng. J. 2019, 365, 20. doi: 10.1016/j.cej.2019.02.023

(20) Wu, W. H.; Huang, X. Y.; Yao, R. M.; Chen, R. J.; Li, K.; Zou, R. Q. Acta Phys.-Chim. Sin. 2017, 33 (1), 255. [吴文昊, 黄心宇, 姚锐敏, 陈人杰, 李凯, 邹如强. 物理化学学报, 2017, 33 (1), 255.] doi: 10.3866/PKU.WHXB201610181

(21) Li, B. L.; Guo, J. G.; Xu, Bing; Xu, H. T.; Dong, Z. j.; Li, X. K. New Carbon Mater. 2020, 35 (5), 567. doi: 10.1016/S1872-5805(20)60510-8

(22) Liu, X.; Deng, H. L.; Zheng, J. H.; Sun, M.; Cui, H.; Zhang, X. H.; Song, G. S. New Carbon Mater. 2020, 35 (5), 576. doi: 10.1016/S1872-5805(20)60511-X
(23) Yang, J.; Tang, L. S.; Bao, R. Y.; Bai, L.; Liu, Z. Y.; Yang, W.; Xie, B. H.; Yang, M. B. J. Mater. Chem. A 2016, 4 (48), 18841. doi: $10.1039 / \mathrm{c} 6 \mathrm{ta} 08454 \mathrm{k}$

(24) Huang, J. H.; Zhang, B. N.; He, M.; Huang, X.; Wu, G. J.; Yin, G. Q.; Cui, Y. D. J. Mater. Sci. 2020, 55 (17), 7337. doi: 10.1007/s10853-020-04514-9

(25) Yang, G. Q.; Zhao, L. Y.; Shen, C. F.; Mao, Z. P.; Xu, H.; Feng, X. L.; Wang, B. J.; Sui, X. F. Sol. Energy Mater. Sol. Cells 2020, 209, 110441. doi: 10.1016/j.solmat.2020.110441

(26) Mu, B. Y.; Li, M. Sol. Energy Mater. Sol. Cells 2019, 191, 466. doi: 10.1016/j.solmat.2018.11.025

(27) Jiang, L. L.; Fan, Z. J. Nanoscale 2014, 6 (4), 1922. doi: $10.1039 / \mathrm{c} 3 \mathrm{nr} 04555 \mathrm{~b}$

(28) Wang, P.; Chong, H. D.; Zhang, J. J.; Lu, H. B. ACS Appl. Mater. Interfaces 2017, 9 (26), 22006. doi: 10.1021/acsami.7b07328

(29) Woltornist, S. J.; Varghese, D.; Massucci, D.; Cao, Z.; Dobrynin, A. V.; Adamson, D. H. Adv. Mater. 2017, 1604947. doi: 10.1002/adma.201604947

(30) Zhong, Y. J.; Zhou, M.; Huang, F. Q.; Lin, T. Q.; Wan, D. Y. Sol. Energy Mater. Sol. Cells 2013, 113, 195. doi: 10.1016/j.solmat.2013.01.046

(31) Yang, J.; Zhang, E. W.; Li, X. F.; Zhang, Y. T.; Qu, J.; Yu, Z. Z. Carbon 2016, 98, 50. doi: 10.1016/j.carbon.2015.10.082

(32) Zhou, Y.; Li, C. H.; Wu, H.; Guo, S. Y. Colloids Surf. A 2020, 597, 124780. doi: 10.1016/j.colsurfa.2020.124780

(33) Zhu, X. Y.; Yang, C.; Wu, P. W.; Ma, Z. Q.; Shang, Y. Y.; Bai, G. Z.; Liu, X. Y.; Chang, G.; Li, N.; Dai, J. J; et al. Nanoscale 2020, 12 (8), 4882. doi: 10.1039/c9nr07861d

(34) Qiu, L.; Liu, J. Z.; Chang, S. L.; Wu, Y. Z.; Li, D. Nat. Commun. 2012, 3, 1241. doi: 10.1038/ncomms 2251

(35) Kashyap, S.; Kabra, S.; Kandasubramanian, B. J. Mater. Sci. 2020, 55 (10), 4127. doi: 10.1007/s10853-019-04325-7

(36) Yan, F.; Liu, L.; Li, M.; Zhang, M. J.; Shang, L.; Xiao, L. H.; Ao, Y. H. Compos. Part A 2019, 125, 105530. doi: 10.1016/j.compositesa.2019.105530

(37) Lu, L.; Shen, Y. F.; Chen, X. H.; Qian, L. H.; Lu, K. Science 2004, 304 (5669), 422. doi: 10.1126/science.1092905

(38) Chen, C. M.; Zhang, Q.; Yang, M. G.; Huang, C. H.; Yang, Y. G.; Wang, M. Z. Carbon 2012, 50 (10), 3572. doi: 10.1016/j.carbon.2012.03.029

(39) Hu, H.; Zhao, Z. B.; Wan, W. B.; Gogotsi, Y.; Qiu, J. S. Adv. Mater. 2013, 25 (15), 2219. doi: 10.1002/adma.201204530

(40) Yang, J.; Qi, G. Q.; Bao, R. Y.; Yi, K. Y.; Li, M. L.; Peng, L.; Cai, Z.; Yang, M. B.; Wei, D. C.; Yang, W. Energy Storage Mater. 2018, 13, 88. doi: 10.1016/j.ensm.2017.12.028

(41) Zhao, J. L.; Luo, W. J.; Kim, J. K.; Yang, J. L. ACS Appl. Energy 
Mater. 2019, 2 (5), 3657. doi: 10.1021/acsaem.9b00374

(42) Tian, B. Q.; Yang, W. B.; Luo, L. J.; Wang, J.; Zhang, K.; Fan, J. H.; Wu, J. Y.; Xing, T. Sol. Energy 2016, 127, 48. doi: 10.1016/j.solener.2016.01.011

(43) Biener, J.; Stadermann, M.; Suss, M.; Worsley, M. A.; Biener, M. M.; Rose, K. A.; Baumann, T. F. Energy Environ. Sci. 2011, 4 (3), 656. doi: $10.1039 / \mathrm{c} 0 \mathrm{ee} 00627 \mathrm{k}$

(44) Xu, Y.; Fleischer, A. S.; Feng, G. Carbon 2017, 114, 334. doi: 10.1016/j.carbon.2016.11.069

(45) Padmajan Sasikala, S.; Poulin, P.; Aymonier, C. Adv. Mater. 2016, 28 (14), 2663. doi: 10.1002/adma.201504436

(46) Balandin, A. A. Nat. Mater. 2011, 10 (8), 569. doi: 10.1038/nmat3064

(47) Zhang, X.; Wan, D. Q.; Peng, K.; Zhang, W. J. Mater. Eng. Perform. 2019, 28 (8), 5165. doi: 10.1007/s11665-019-04212-x

(48) Gao, W. W.; Zhao, N. F.; Yao, W. Q.; Xu, Z.; Bai, H.; Gao, C. RSC Adv. 2017, 7 (53), 33600. doi: 10.1039/c7ra05557a

(49) Almajali, M.; Lafdi, K.; Prodhomme, P. H.; Ochoa, O. Carbon 2010,
48 (5), 1604. doi: 10.1016/j.carbon.2009.12.060

(50) Cao, A. Y.; Dickrell, P. L.; Sawyer, W. G.; Ghasemi-Nejhad, M. N.; Ajayan, P. M. Science 2005, 310 (5752), 1307. doi: $10.1126 /$ science. 1118957

(51) Zhang, Q. Q.; Lin, D.; Deng, B. W.; Xu, X.; Nian, Q.; Jin, S. Y.; Leedy, K. D.; Li, H.; Cheng, G. J. Adv. Mater. 2017, 29 (28), 69469. doi: 10.1002/adma.201605506

(52) Park, J. H.; Lee, J. H.; Soon, A. Phys. Chem. Chem. Phys. 2016, 18 (31), 21893. doi: 10.1039/c6cp03249d

(53) He, L. J.; Mo, S. P.; Lin, P. C.; Jia, L.; Chen, Y.; Cheng, Z. D. Appl. Energy 2020, 268. 115020. doi: 10.1016/j.apenergy.2020.115020

(54) Liang, K.; Shi, L.; Zhang, J. Y.; Cheng, J.; Wang, X. D. Thermochim. Acta 2018, 664, 1. doi: 10.1016/j.tca.2018.04.002

(55) Shen, J.; Zhang, P.; Song, L. X.; Li, J. P.; Ji, B. Q.; Li, J. J.; Chen, L. Compos. Part B 2019, 179, 107545.

doi: 10.1016/j.compositesb.2019.107545 